\title{
Youngest Cretaceous dinosaur tracksite from the Middle East (Maastrichtian, Farrokhi Formation, Central Iran)
}

\author{
Markus Wilmsen $^{1} \cdot$ Franz Theodor Fürsich ${ }^{2} \cdot$ Mahmoud Reza Majidifard $^{3}$
}

Received: 11 June 2021 / Revised: 19 August 2021 / Accepted: 16 September 2021 / Published online: 7 December 2021

(C) The Author(s) 2021, corrected publication 2022

\begin{abstract}
A late early Maastrichtian dinosaur trampling site is reported from the Farrokhi Formation of the Khur area, Central Iran. The largely indeterminate footprints, some of which may represent undertracks, can be classified as natural moulds (i.e. concave epireliefs) bordered by a raised rim of displaced sediment. They reach diameters of up to $0.5 \mathrm{~m}$ and were impressed under very shallow to subaerial conditions in an inter- to supratidal environment. Two generations of traces have been imprinted, initially into a soft, fine-grained carbonate sand and afterwards into a superficially hardened substrate that was still plastic underneath; the change in substrate consistency is supported by a conspicuous cracking pattern around the footprints. As a result, hardly any details of the foot morphology of the trackmakers are recorded. Nevertheless, the occurrence improves our knowledge about dinoturbation and its preservation in different kinds of substrates. Furthermore, it is the youngest record (ca. $70 \mathrm{Ma}$ ) of dinosaur locomotion traces from Iran and, in all probability, the entire Middle East.
\end{abstract}

Keywords Late Cretaceous · Yazd Block · Tidal flats · Dinoturbation · Emersion · Composite surface

\section{Introduction}

Cretaceous strata are very well exposed around Khur, in the northern part of the Yazd Block, Central Iran. After early mapping surveys (Aistov et al. 1984), the Cretaceous succession was the subject of a joint Iranian-German research initiative in the last decade (see summary in Wilmsen et al. 2015), and the integrated stratigraphy, depositional environments, and geodynamic significance of individual

Markus Wilmsen

markus.wilmsen@senckenberg.de

Franz Theodor Fürsich

franz.fuersich@fau.de

Mahmoud Reza Majidifard

m_majidifard@yahoo.com

1 Senckenberg Naturhistorische Sammlungen Dresden, Museum für Mineralogie und Geologie, Sektion Paläozoologie, Königsbrücker Landstr. 159, 01109 Dresden, Germany

2 GeoZentrum Nordbayern, Fachgruppe Paläoumwelt, Friedrich-Alexander-Universität Erlangen-Nürnberg, Loewenichstr. 28, 91054 Erlangen, Germany

3 Research Institute for Earth Sciences, Geological Survey of Iran, Box 131851-1494, Tehran, Iran formations and major unconformities were detailed in several publications (Wilmsen et al. 2013, 2018a, b, 2020). During a field survey in 2012, a dinosaur trampling site was discovered within the upper Campanian-Maastrichtian Farrokhi Formation and it was revisited and restudied in 2018. The aim of the current short note is the first report and scientific description of the site that supplements the sparse Mesozoic record of dinosaur tracksites from Iran (see Lapparent and Davoudzadeh 1972; Lapparent and Nowgol Sadat 1975; Ataabadi et al. 2005; Abbassi 2006; Kellner et al. 2012; Abbassi and Madanipour 2014; Abbassi et al. 2015, 2018), representing the youngest hitherto known occurrence. With our report, we also hope to stimulate further research on that topic in the area north of Khur where, in the future, additional and better-preserved tracks may emerge from the Farrokhi Formation.

\section{Geological setting and stratigraphy}

The study area is located in the north-western part of the Central-East Iranian Microcontinent (CEIM; Takin 1972), occupying a structural key position in the complicated plate tectonic puzzle of the Middle East and consisting of three structural units, the Lut, Tabas, and Yazd blocks, 
respectively (Fig. 1a). The CEIM, Northwest Iran, the Alborz Mountains, and the Binalud Mountains form the Iran Plate that, as an element of the ribbon-like Cimmerian terrane assemblage, split off from the northern margin of Gondwana towards the end of the Palaeozoic Era (Late Permian; e.g. Stampfli and Borel 2002; Shamanian and Hattori 2021). The northward-directed drift of the Cimmerian terranes opened the Neotethys, and their collision with the southern
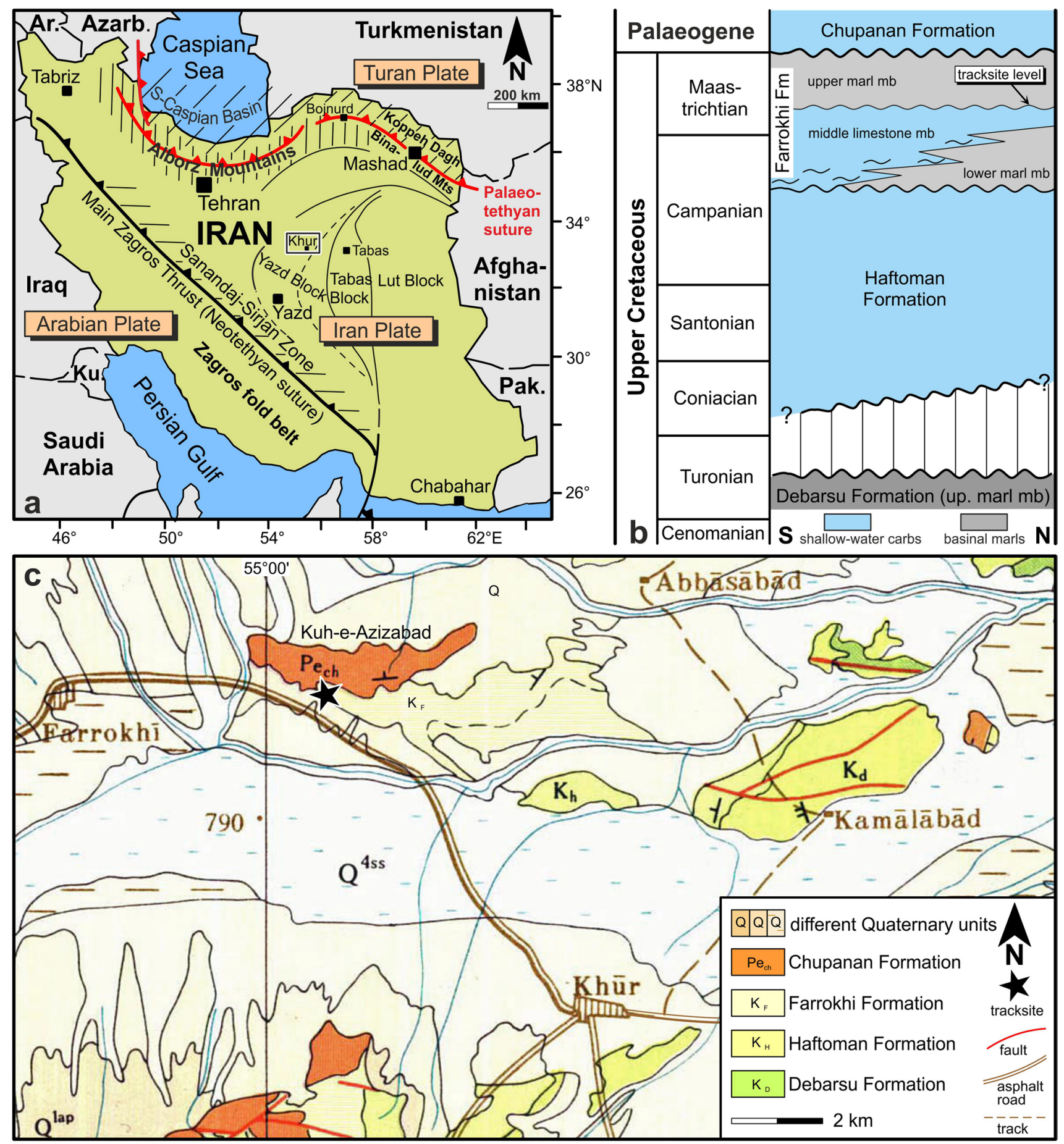

Fig. 1 Structural and geological setting and lithostratigraphic framework of the Maastrichtian dinosaur tracksite in the Farrokhi Formation of Central Iran. a Main structural units and sutures of Iran; the small rectangle shows the study area near Khur in the northern part of the Yazd Block (compare to c). b Lithostratigraphy of the area around
Khur, simplified after Aistov et al. (1984) and Wilmsen et al. (2015). c Location of the dinosaur tracksite (asterisk), ca. $10 \mathrm{~km}$ northwest of Khur at the southern flank of Kuh-e-Azizabad (geological base map modified from Aistov et al. 1984) 
margin of Eurasia (Turan Plate) closed the Palaeotethys Ocean during the Late Triassic (e.g. Berberian and King 1981; Sengör et al. 1988; Saidi et al. 1997; Wilmsen et al. 2009). After its welding to Eurasia, the Iran Plate remained a tectonically highly mobile area in Jurassic times (e.g. Fürsich et al. 2003; Seyed-Emami et al. 2004; Taheri et al. 2009; Salehi et al. 2018; Wilmsen et al. 2021). During the Early Cretaceous, strongly subsiding marginal oceans formed around the CEIM (Tirrul et al. 1983; Babazadeh and De Wever 2004; Nasrabady et al. 2011; Kazemi et al. 2019; Pirnia et al. 2020), probably in response to counterclockwise vertical-axis rotation of the microplate (e.g. Soffel et al. 1996; Alavi et al. 1997; Besse et al. 1998; Cifelli et al. 2013; Mattei et al. 2015; Wilmsen et al. 2021) and the break-up of deep-seated faults along its margins. The convergence of Arabia and Eurasia led to the closure of the narrow oceanic basins fringing the CEIM during the latest Cretaceous to Paleogene (e.g. Omrani et al. 2013; Delavari et al. 2014; Kazemi et al. 2019 ).

The Cretaceous succession in the Khur area, northern Yazd Block, attains a thickness of up to $5 \mathrm{~km}$ and has been subdivided into two large-scale transgressive-regressive megacycles based on a major late Turonian-early Coniacian tectonic event (Wilmsen et al. 2015). The resulting tectonic unconformity is regionally expressed by a coarsegrained and in places very thick conglomerate at the base of the Haftoman Formation, associated with block-faulting and deep-cutting erosion. The widespread and uniform carbonate facies of the overlying Coniacian-upper Campanian Haftoman Formation (Fig. 1b) reflects the establishment of a large-scale epeiric carbonate platform and an intermittent decline of tectonic instability (Wilmsen et al. 2018a). In the late Campanian, marls of the lower Farrokhi Formation onlap a subaerial surface at the top of the Haftoman Formation north of Khur, while the platform persisted in the southern part of the study area (Fig. 1b). Renewed northward progradation of the platform in the latest Campanian resulted in an intercalation of a middle limestone tongue of the Farrokhi Formation in the area north of Khur, capped by another subaerial surface. Maastrichtian marls and thinbedded, fine-grained limestones of the upper Farrokhi Formation onlap the subaerial surface and indicate somewhat deeper marine conditions across the study area towards the end of the Cretaceous Period (Wilmsen et al. 2012). With a basal conglomerate, Paleocene carbonates of the Chupanan Formation rest unconformably on the Cretaceous succession (Fig. 1b).

The Farrokhi Formation has broadly been dated as Campanian-Maastrichtian by Aistov et al. (1984). Allameh and Nejad (2017) reproduced an early Campanian to late Maastrichtian age in the type area based on planktic foraminifers but obviously included the upper Haftoman Formation into their analysis. Correspondingly, Wilmsen et al. (2018a) showed that north of Farrokhi, the eponymous formation starts above an unconformity at the top Haftoman Formation in the mid-late Campanian. Based on planktic foraminifers, the overlying lower marl member of the Farrokhi Formation is late Campanian to earliest Maastrichtian in age, including the Globotruncana aegyptiaca and Gansserina gannsseri zones (Elyasi, 2017). No age data are available for the middle limestone member of the Farrokhi Formation, but the overlying upper marl member has a latest early to late Maastrichtian age based on a diverse assemblage of planktic and benthic foraminifers (Elyasi 2017). Thus, a late early Maastrichtian age can be assigned to the tracksite at the top of the middle limestone member of the Farrokhi Formation (ca. $70 \mathrm{Ma}$ according to the new GTS 2020; Gale et al. 2020).

\section{Materials and methods}

Two field surveys were conducted in 2012 and 2018, applying standard palaeontological and sedimentological field methods (e.g. Goldring 1999; Stow 2005; Tucker 2011). Field-based grain-size and component analyses using a handlens were detailed later by microfacies analysis of thin-sections that have been prepared from characteristic lithofacies identified in the field, using a Leica M125 stereomicroscope with a Leica DFC 420 digital camera capturing images in the optical pathway. The classification of carbonate rocks follows Dunham (1962). Taphonomic observations at the tracksite were accompanied by a detailed photo-documentation as well as measurements and descriptions of individual tracks, following the terminology of Leonardi (1987). The track-bearing surface was traced along-strike for about $2 \mathrm{~km}$ towards the southeast. Thin-sections are stored in the palaeozoological collections of the Museum für Mineralogie und Geologie (MMG), Senckenberg Naturhistorische Sammlungen Dresden (SNSD), repository MMG: AsK.

\section{Results}

Section and microfacies

The tracksite is located ca. $10 \mathrm{~km}$ northwest of Khur, north of the road to Farrokhi and south of a low-lying, E-W-trending mountainous elevation known as Kuh-e-Azizabad (coordinates: N 33.850600, E 55.031030; Fig. 1c). The exposed stratigraphic succession starts with thick-bedded limestones of the middle Farrokhi Formation (Figs. 1b and 2a). Along an iron-stained emersion surface, the limestones are unconformably overlain by marls and thin-bedded limestone of the upper Farrokhi Formation (Figs. 2a. b and 3). The succession is concluded by the thick-bedded, brown carbonates of the Paleocene Chupanan Formation, which rest along a 

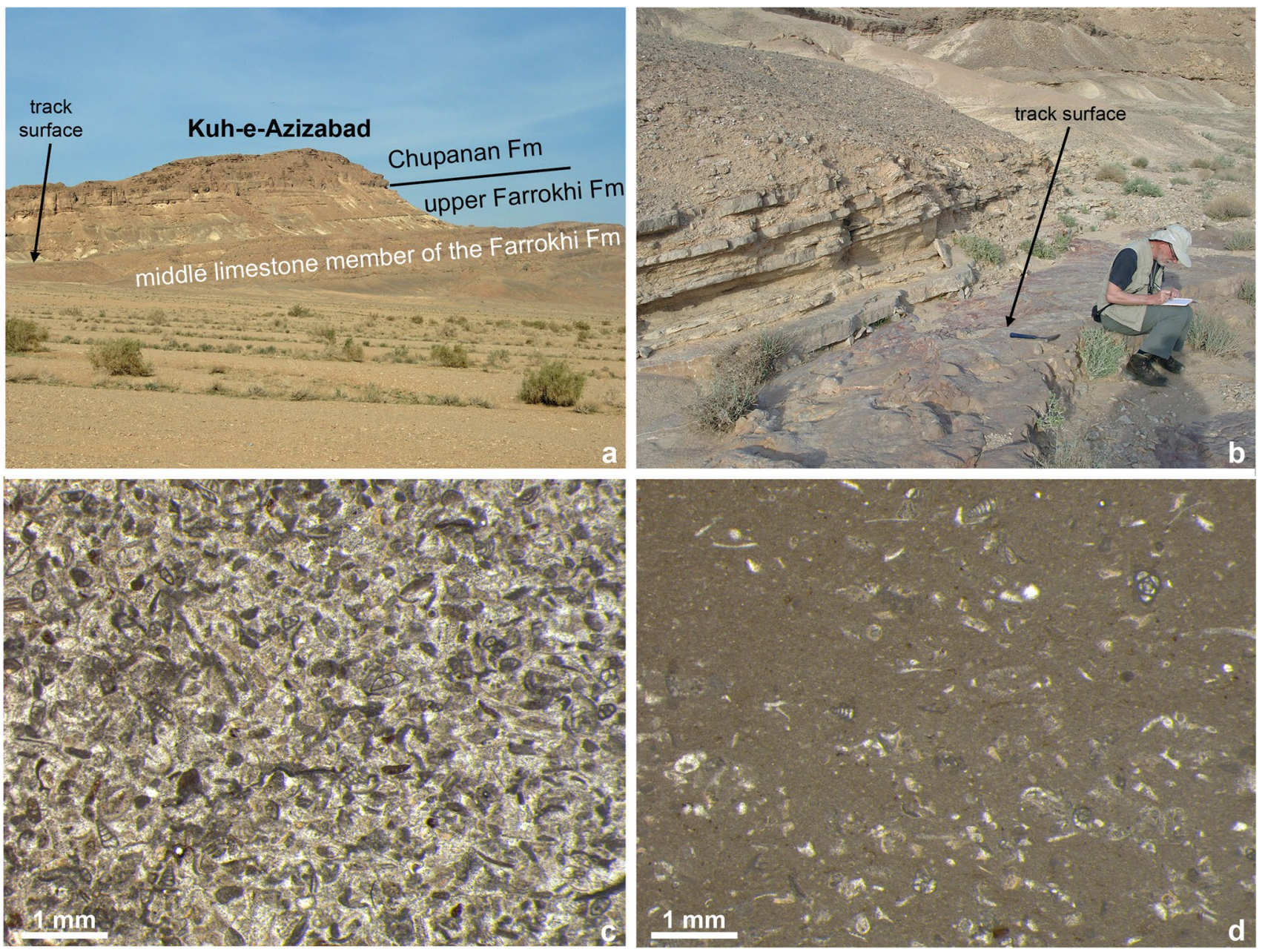

Fig. 2 Field and microfacies aspects of the Maastrichtian dinosaur tracksite in the Farrokhi Formation of Central Iran. a Panoramic view of the stratigraphic succession at Kuh-e-Azizabad: middle limestone member of the Farrokhi Formation overlain by soft-weathering marls and thin-bedded limestones of the upper Farrokhi Formation, followed by the brown, thick-bedded carbonates of the Paleogene Chupanan Formation; the level of the tracksite is arrowed. b Detailed view of the track-bearing surface; note the patchy red staining of the

major erosional unconformity on the Farrokhi Formation (Fig. 2a).

The contact between the middle and the upper member of the Farrokhi Formation is marked by an irregular surface with a relief of up to $20 \mathrm{~cm}$ and patchily distributed ferruginous pigmentation (Figs. $2 \mathrm{~b}$ and 3 ). At this level, the footprints were observed. The underlying beige-brown limestones are well-sorted bio- and intraclastic packstones containing intraclasts, bahamite peloids, small shell fragments of bivalves and echinoderms, as well as small agglutinating and miliolid foraminifers (Fig. 2c). The thin-bedded limestones and marls of the lowermost part of the upper member of the Farrokhi Formation that are sealing

surface and the superposition with thin-bedded grey marls and limestones of the upper member of the Farrokhi Formation. c Well-sorted intra- and bioclastic packstone of the uppermost bed of the middle limestone member of the Farrokhi Formation in which the tracks are imprinted (sample 181016-3). d The transgressive strata of the upper marl member of the Farrokhi Formation sealing the track-bearing surface are composed of fine-grained skeletal wackestone with small benthic foraminifera and ostracods (sample 181016-4)

the relief at the top of the middle member are slightly silty, fine-grained bioturbated wackestones with small benthic foraminifers, ostracods, and microbioclasts (Fig. 2d). On elevated parts of the contact surface, bivalve borings were observed (Fig. 3).

At the described site, a small ephemeral creek provided clean exposures of the contact surface between the middle and the upper member of the Farrokhi Formation. We followed the track level for about $2 \mathrm{~km}$ along-strike at the southern flank of Kuh-e-Azizabad but could not find a better exposure. Only some indifferent impressions were observed at places, showing that tracks potentially have a wider distribution on the surface. 


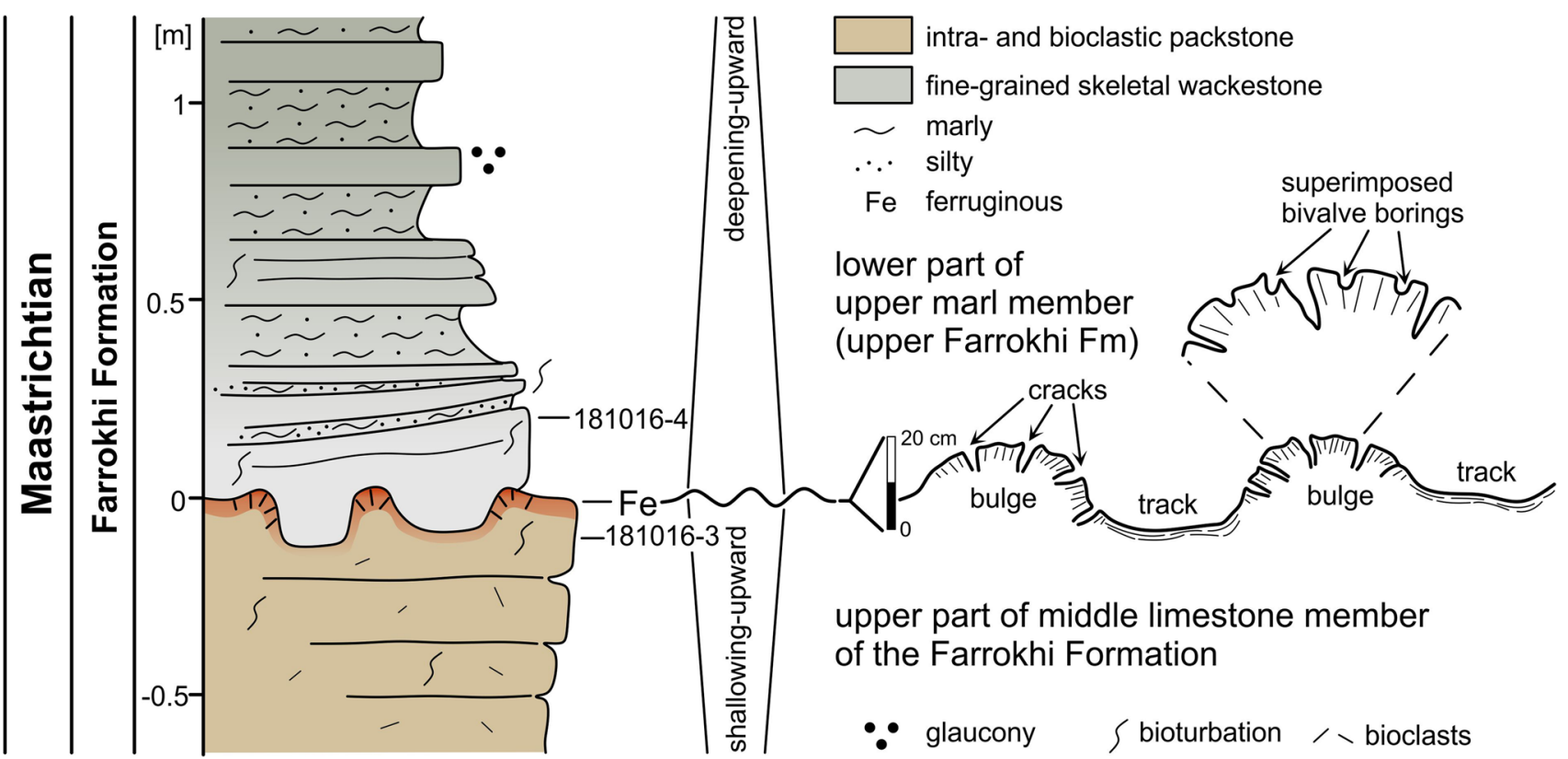

Fig. 3 Detailed stratigraphic log of the Maastrichtian tracksite interval observed at the boundary from the middle to the upper member of the Farrokhi Formation of Central Iran

Tracksite and track description

The tracksite comprises a surface of approximately $20 \mathrm{~m}^{2}$ $(10 \times 2 \mathrm{~m})$, which is riddled with predominantly irregular, indifferent depressions 10 to $50 \mathrm{~cm}$ in diameter (Fig. 4a). The depressions, identified as tracks, are between 7 and $14 \mathrm{~cm}$ deep and commonly have steep margins with raised rims. In some cases, individual imprints are superimposed, forming composite, laterally coalescing depressions (Fig. 4a, b). According to lateral and vertical relationships as well as to the different fabrics of the impressions, two generations of imprints can be identified. The first generation is impressed into beige-brown carbonates and shows very irregular shapes and outlines, including the formation of sub-parallel bulges and overhanging margins (Fig. 4b, c). No cracking of the substrate or iron-staining has been observed with these imprints. The second generation is associated with a ferruginous staining and a conspicuous cracking pattern (Fig. 4e-i). The sloping margins of, and raised bulges between, individual impressions are cracked and partly elevated by having been squeezed-up (Fig. 4h, i), forming a polygonal shard pattern. In several cases, elongated cracks trace the outline of individual impressions, but short cracks also extend in a radial fashion. Better preserved individual footprints include a tridactyl impression more than $50 \mathrm{~cm}$ wide (Fig. 4d), sub-circular to oval imprints with differentiated terminations on one side (Fig. 4e, f) and a deeply indented acute termination superimposed onto a sub-circular track (Fig. 4g).

\section{Discussion}

There is only a very sparse Mesozoic record of dinosaur tracks from Iran (Lapparent and Davoudzadeh 1972; Lapparent and Nowgol Sadat 1975; Ataabadi et al. 2005; Abbassi 2006; Kellner et al. 2012; Abbassi and Madanipour 2014; Abbassi et al. 2015, 2018). The bulk of the records is from the Lower and Middle Jurassic Ab-Haji Subgroup of the Shemshak Group of northern and Central Iran, and the uppermost Jurassic Ravar Formation of the Kerman area. The only Cretaceous reports so far are rather small sauropod and stegosaur footprints from Aptian strata of the Tirgan Formation of the Koppeh Dagh Basin in northeastern Iran (Abbassi et al. 2018).

The general appearance of the surface suggests that it represents a kind of "trampled dinosaur parade". Such kind of indifferent dinosaur-induced bioturbation produced by individuals clattering around has been termed "dinoturbation" (Dodson et al. 1980; see also Thulborn 1990; Lockley 1991). According to the relative degree of trampling, a moderate dinoturbation index can be assigned to the Farrokhi site (cf. Lockley and Conrad 1989). The imprints can be classified as natural moulds (i.e. concave epireliefs sensu Leonardi 1987) with footprints bordered by a raised rim of displaced sediment (see Leonardi 1987; Thulborn 1990). The two generations described above were probably made at different times based on the different modes of preservation of the footprints. The first (earlier) generation was imprinted into a soft substrate (fine-grained carbonate sand with 

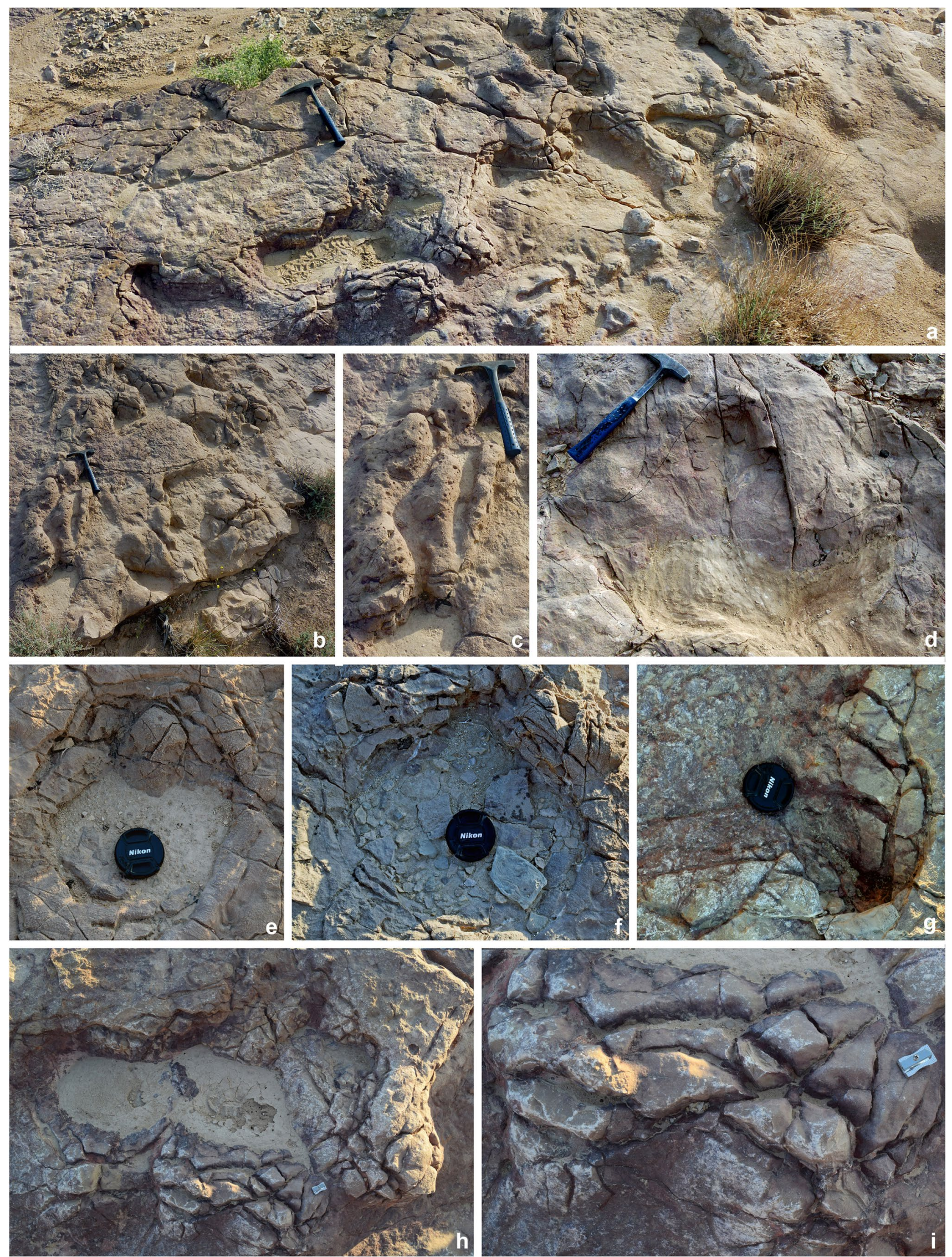
4Fig. 4 Photo-documentation of the Maastrichtian dinosaur tracksite in the Farrokhi Formation of Central Iran. a General view of the central part of the exposed track layer; note steep margins and elevated bulges (length of hammer: $33 \mathrm{~cm}$ ). b Trampled surface without cracks (first generation of tracks); note partly overhanging walls and the absence of the iron-staining (28-cm-long hammer gives scale). c Detail of $\mathbf{b}$ : subparallel bulges testify the non-lithified, muddy nature of the substrate when these tracks were produced (length of hammer: $28 \mathrm{~cm}$ ). d Tridactyl imprint more than $50 \mathrm{~cm}$ in width (length of hammer: $33 \mathrm{~cm}$ ). e Sub-circular footprint with a one-sided terminal differentiation towards the top of the image (digit traces?); lens cap $55 \mathrm{~mm}$ in diameter. f Another sub-circular footprint with a one-sided differentiation (top of image); note the concentric crack pattern around the imprint (lens cap $55 \mathrm{~mm}$ in diameter). g Potential claw imprint; note the cracking of the hardened upper surface when the soft substrate below has been indented (lens cap $55 \mathrm{~mm}$ in diameter). h Composite impression with cracked margins and bulges (length of pencil sharpener: $25 \mathrm{~mm}$ ). i Detail of a cracked bulge; note sub-parallel nature of cracks (length of pencil sharpener: $25 \mathrm{~mm}$ )

micritic matrix) that was squeezed out under the load of the trampling animal. Due to its consistency, the substrate was deformed without rupturing. The existence of overhanging walls suggests that the traces were preserved as undertracks and the created relief was immediately filled with overlying, still softer sediment. Details of the imprinting feet could not be preserved because the sediment was too soft (see also Sarjeant and Leonardi 1987). The second (later) generation was made some time afterwards when the layer had become superficially hardened. When loaded, the hardened surface failed and the trackmakers sunk into the still plastic layer below. However, again the substrate did not have the ideal consistency to preserve any details of the footprints, as below the few centimetres-thick hardened layer, the sediment was still soft. As a result, a rather irregular morphology was created, bordered by raised rims of displaced sediment covered by a cracked, mosaic-like layer. It is also possible that the cementation took place not right at the top surface but some centimetres below. The iron-staining was most likely formed under persistent subaerial exposure under (semi-)arid conditions and accompanied by further lithification of the surface. Similar climatic conditions have been proved for the underlying platform carbonates of the Coniacian-Campanian Haftoman Formation by the occurrence of intercalated red beds, gypsum nodules, and iron-stained karst surfaces (Wilmsen et al. 2018a).

The small sauropod and stegosaur footprints reported from Aptian strata of the Tirgan Formation of the Koppeh Dagh (NE Iran) were produced under subaerial conditions in an intertidal environment (Abbassi et al. 2018) and several other Mesozoic dinosaur tracksites have been reported from inter- to supratidal settings (e.g. Marty et al. 2003, 2018; Marty 2008; Razzolini et al. 2016); the same conditions apply for the footprints in the Maastrichtian Farrokhi Formation. Putting all available data together, a genetic model for the formation of the surface yielding the tracksite can be developed (Fig. 5): progressive shallowing towards the top of the middle member of the Farrokhi Formation during the late early Maastrichtian caused extremely shallow conditions and a first trampling of the soft, water-saturated sediments occurred (first generation of imprints; Fig. 5a). Subaerial exposure resulted in a subsequent initial hardening of the surface (Fig. 5b) or of a sediment layer some centimetres below the surface. At this stage, a second generation of footprints was imprinted, characterised by the conspicuous cracking patterns around the tracks (Fig. 5c). Further lithification of the layer during a subsequent prolonged emersion period produced a true hardground that became iron-stained under the prevailing (semi-)arid climate (Fig. 5d). This composite surface was bored by bivalves during the following late Maastrichtian transgression (Fig. 5e) and draped by fine-grained calcareous offshore sediments of the upper marl member of the Farrokhi Formation when accommodation was created during progressive deepening (Fig. 5f). An alternative interpretation for the differential preservation of the footprints may be that the two types of footprints are contemporaneous and the substrate consistency changed laterally (e.g. by the persistence of small ponds on the developing emersion surface). In this case, stages a and $\mathrm{c}$ in Fig. 5 need to be merged into one time slice.

Based on the poor preservation of the footprints, mainly related to the unfavourable substrate conditions (cf. Sarjeant and Leonardi 1987; Marchetti et al. 2019), we can neither comment on the trackmakers nor on the ichnotaxonomic affinity of the traces. We have several round to oval footprints (Figs. 4e, f and 6a-c), one tridactyl form (Figs. 4d and $6 \mathrm{e}$ ), a possible claw trace (Fig. 4g), and composite tracks resulting from repeated trampling of the surface (Figs. 4a, $\mathrm{h}$ and $6 \mathrm{f}-\mathrm{h}$ ); the numerous round to faintly oval imprints may be related to quadrupedal trackmakers, most likely sauropods, but no detailed conclusions are possible based on the poor to very poor morphological preservation of the tracks (cf. Marchetti et al. 2019). Consequently, the track surface in the Farrokhi Formation provides only a general indication of the passage of dinosaurs in an inter- to supratidal environment but very little information can be obtained about the potential trackmakers. Nevertheless, the occurrence enhances our knowledge on the preservation of dinoturbation in different kinds of substrates. Furthermore, the young, foraminifer-calibrated late early Maastrichtian age at the top of the middle limestone member of the Farrokhi Formation (cf. Elyasi 2017; ca. 70 Ma according to the new GTS 2020; Gale et al. 2020) places the tracksite in the evolutionary twilight close to dinosaur extinction at the end of the Cretaceous Period. The site is among the youngest dinosaur tracksites worldwide (e.g. Difley and Ekdale, 2002; Vremir and Codrea, 2002; Vila et al., 2013; Flaig et al., 2018; Meyer et al., 2021) and is by far the youngest record from Iran (see references above). Furthermore, there are only 
Fig. 5 Genetic model for the development of the Maastrichtian dinosaur tracksite found in the Farrokhi Formation of Central Iran from older below (a) to younger above (f) (not to scale; the successive trampling is shown in opposite directions for better differentiation of the two track generations). a First generation of tracks produced under very shallow conditions in a soft, fine-grained carbonate sand with micritic matrix (uppermost part of the middle limestone member of the Farrokhi Formation). b Emersion and initial hardening of the trampled surface following continuous relative sea-level fall. c Second generation of tracks imprinted into superficially hardened sediment that was still plastic underneath; conspicuous cracking pattern developed around imprints. d Subsequent long-term exposure of the surface caused subaerial lithification of the strata. e During the following late Maastrichtian transgression, the hardground was patchily bored by bivalves. f Further deepening during the late Maastrichtian transgression created accommodation and the composite surface was sealed by fine-grained, calcareous offshore sediments of the upper marl member of the Farrokhi Formation

a few Cretaceous dinosaur tracksites known from the Middle East at all (e.g. Avnimelech 1962; Schulp et al. 2008; Gèze et al. 2016; Klein et al. 2020) that are all significantly older, and it thus appears that the discovery from the Farrokhi Formation of Central Iran is also the youngest record in the entire Middle East.

\section{Conclusions}

A Maastrichtian dinosaur tracksite from northwest of Khur is reported from the Farrokhi Formation of Central Iran. It has been found at the junction of the middle to the upper member of the Farrokhi Formation and it was associated with subaerial exposure in a tidal flat environment. Biostratigraphic data indicate a late early Maastrichtian age for the tracks. The largely indeterminate footprints represent natural moulds (= concave epireliefs) bordered by raised rims of displaced sediment. Two generations of footprints were imprinted under extremely shallow to subaerial conditions related to an episode of sea-level fall, firstly into a soft fine-grained carbonate sand and, at a later stage, into a partially cemented substrate that was underlain by still plastic sediment. Evidence of partial lithification is a conspicuous cracking pattern around the footprints. Further lithification of the track-bearing surface was followed by formation of an iron-stained hardground. Finally, the dinoturbated horizon was sealed by the upper member of the Farrokhi Formation during the following late Maastrichtian transgression. Unfortunately, no anatomical details of the foot morphologies of the producers were recorded due to the unfavourable substrate conditions, and we thus can neither comment on the actual trackmakers nor on the ichnotaxonomic affinity of the traces. Nevertheless, the surface documents a kind of

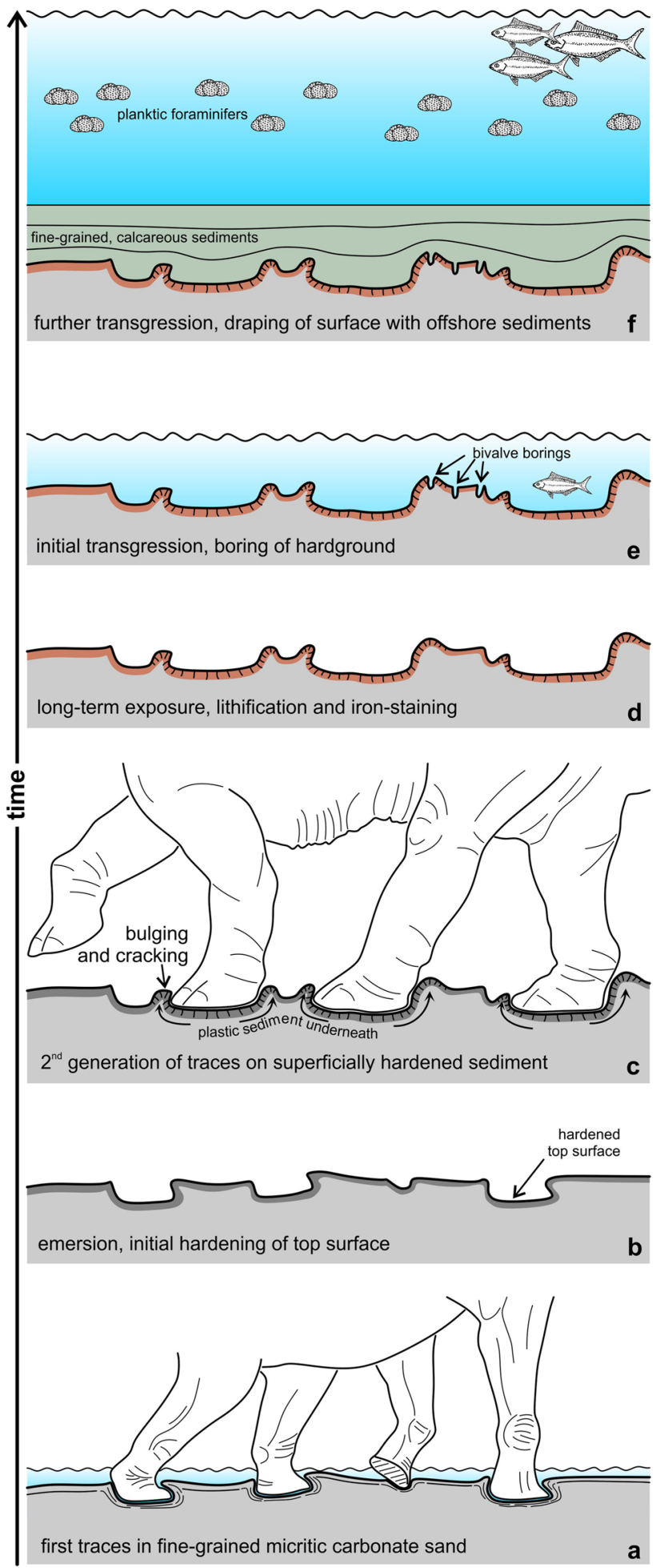

trampled dinosaur parade, representing a fine case of dinoturbation. Moreover, it is the youngest record (ca. $70 \mathrm{Ma}$ ) of dinosaur locomotion traces from Iran and, to the best of our knowledge, from the entire Middle East. 


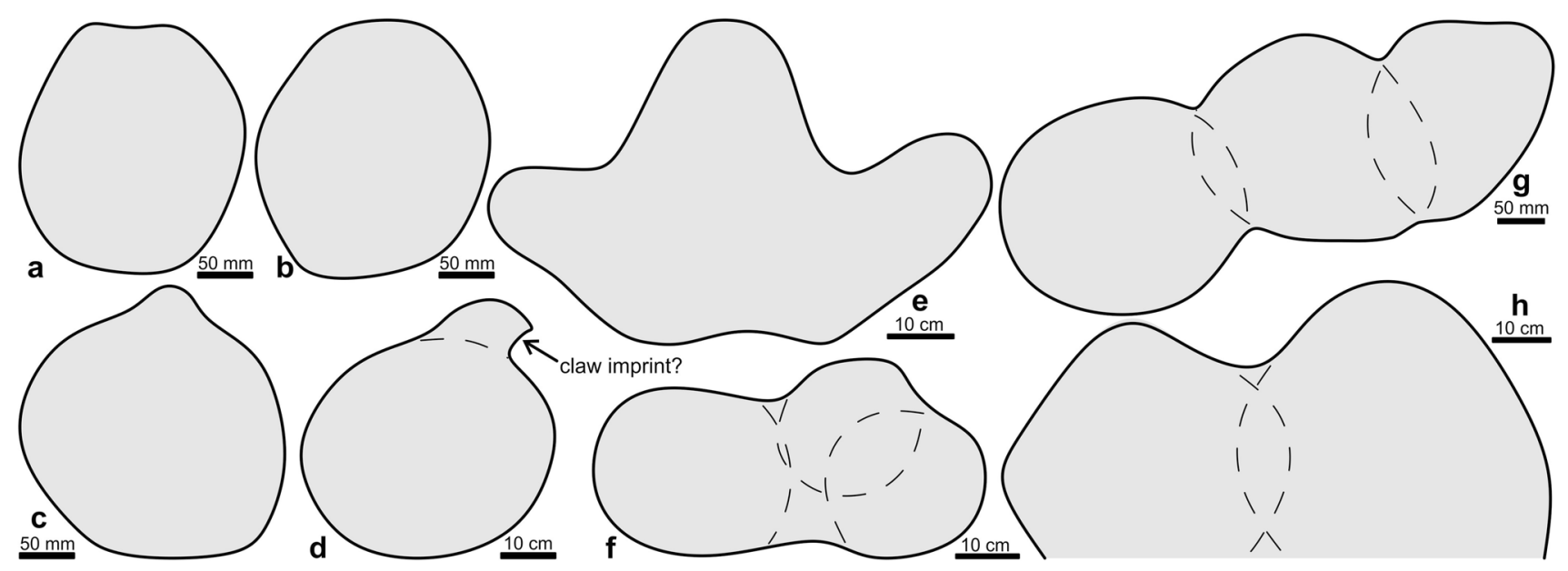

Fig. 6 Outlines of different tracks observed. a-d Sub-circular to faintly oval imprints (possible sauropod tracks) with (d) showing a superimposed potential claw imprint. e Tridactyl imprint. $\mathbf{f}-\mathbf{h}$ Composite tracks resulting from repeated trampling of the substrate

Acknowledgements We acknowledge constructive reviews by M. Antonelli (Rome) and M. Belvedere (Florence) that significantly improved the quality of the original manuscript. Furthermore, we are indebted to the Geological Survey of Iran for continuous logistic support. We also thank M. Berensmeier (Vienna) and V. Hairapetian (Esfahan) for companionship during the 2018 visit to the tracksite. Finally, MW acknowledges an e-mail discussion of the tracksite with F.M. Dalla Vecchia (then Sabadell) in 2013. Ronald Winkler (Dresden) prepared the thin-sections with great care.

Funding Open access funding provided by Senckenberg Naturhistorische Sammlungen Dresden (3507).

\section{Declarations}

Conflict of interest The authors declare that they have no conflict of interest.

Open Access This article is licensed under a Creative Commons Attribution 4.0 International License, which permits use, sharing, adaptation, distribution and reproduction in any medium or format, as long as you give appropriate credit to the original author(s) and the source, provide a link to the Creative Commons licence, and indicate if changes were made. The images or other third party material in this article are included in the article's Creative Commons licence, unless indicated otherwise in a credit line to the material. If material is not included in the article's Creative Commons licence and your intended use is not permitted by statutory regulation or exceeds the permitted use, you will need to obtain permission directly from the copyright holder. To view a copy of this licence, visit http://creativecommons.org/licenses/by/4.0/.

\section{References}

Abbassi, N. (2006). New Early Jurassic dinosaur footprints from Shemshak Formation, Harzavil village, western Alborz, north Iran. Scientific Quarterly Journal of Geoscience, Geological Survey of Iran, 16, 30-37. [in Persian with English abstract]

Abbassi, N., \& Madanipour, S. (2014). Dinosaur tracks from Jurassic Shemshak Group in Central Alborz Mountains, Northern Iran. Geologica Carpathica, 65, 99-115.
Abbassi, N., D’Orazi Porchetti, S., Wagensommer, A., \& Ghorbani Dehnavi, M. (2015). Dinosaur and crocodylomorph footprints from the Hojedk Formation (Bajocian, Middle Jurassic) of north Kerman, Central Iran. Italian Journal of Geoscience, 134, 86-94.

Abbassi, N., Alimohammadian, H., Shakeri, S., Broumand, S., \& Broumand, A. (2018). Aptian small dinosaur footprints from the Tirgan Formation, Kopet-Dagh Region, northeastern Iran. New Mexico Museum of Natural History and Science Bulletin, 80, 5-14.

Aistov, L., Melnikov, B., Krivyakin, B., Morozov, L., \& Kiristaev, V. (1984). Geology of the Khur area (Central Iran). Explanatory text of the Khur quadrangle map 1:250.000. V/O Technoexport, Report, 20, 1-132.

Alavi, M., Vaziri, H., Seyed-Emami, K., \& Lasemi, Y. (1997). The Triassic and associated rocks of the Nakhlak and Aghdarband areas in central and northeastern Iran as remnants of the southern Turan active continental margin. Geological Society of America Bulletin, 109, 1563-1575.

Allameh, M., \& Nejad, R. R. Y. (2017). Late Cretaceous biostratigraphy planktonic foraminifera of the Farokhi Formation, Iran. Open Journal of Geology, 7, 320-334.

Ataabadi, M. M., Kellner, A. W. A., Della Vecchia, F. M., \& Paula Silva, H. (2005). Palaeoichnology and palaeontology of dinosaurs in north of Kerman, south east Central Iran. Geosciences Scientific Quarterly Journal, 14(54), 36-47.

Avnimelech, M. A. (1962). Dinosaur tracks in the Lower Cenomanian of Jerusalem. Nature, 196, 264.

Babazadeh, S. A., \& De Wever, P. (2004). Radiolarian Cretaceous age of Soulabest radiolarites in ophiolite suite of eastern Iran. Bulletin De La Societé Géologique De France, 175, 121-129.

Berberian, M., \& King, G. C. P. (1981). Towards a palaeogeography and tectonic evolution of Iran. Canadian Journal of Earth Sciences, 18, 210-265.

Besse, J., Torcq, F., Gallet, Y., Ricou, L. E., Krystyn, L., \& Saidi, A. (1998). Late Permian to Late Triassic palaeomagnetic data from Iran: Constraints on the migration of the Iranian block through the Tethyan Ocean and initial destruction of Pangaea. Geophysical Journal International, 135, 77-92.

Cifelli, F., Mattei, M., Rashid, H., \& Ghalamghash, J. (2013). Rightlateral transpressional tectonics along the boundary between Lut and Tabas blocks (Central Iran). Geophysical Journal International, 193, 1153-1165. 
Delavari, M., Amini, S., Schmitt, A. K., McKeegan, K. D., \& Harrison, T. M. (2014). U-Pb geochronology and geochemistry of BibiMaryam pluton, eastern Iran: Implication for the late stage of the tectonic evolution of the Sistan Ocean. Lithos, 200-201, 197-211.

Difley, R. L., \& Ekdale, A. A. (2002). Footprints of Utah's last dinosaurs: Track beds in the Upper Cretaceous (Maastrichtian) North Horn Formation of the Wasatch Plateau, central Utah. Palaios, 17, 327-346.

Dodson, P., Behrensmeyer, A. K., Bakker, R. T., \& McIntosh, J. S. (1980). Taphonomy and paleoecology of the dinosaur beds of the Jurassic Morrison Formation. Paleobiology, 6, 208-232.

Dunham, R. J. (1962). Classification of carbonate rocks according to depositional texture. In W. E. Ham (Ed.), Classification of carbonate rocks. American Association of Petroleum Geologists Memoir, $1,108-121$.

Elyasi, S. (2017). Stratigraphy of Farrokhi Formation in the northwest of Khour (Central Iran) (pp. 1-182). unpublished master thesis. Tehran: Research Institute for Earth Sciences. [in Farsi]

Flaig, P. P., Hasiotis, S. T., \& Fiorillo, A. R. (2018). A paleopolar dinosaur track site in the Cretaceous (Maastrichtian) Prince Creek Formation of Arctic Alaska: Track characteristics and probable trackmakers. Ichnos, 25, 208-220.

Fürsich, F. T., Wilmsen, M., Seyed-Emami, K., \& Majidifard, M. R. (2003). Evidence of synsedimentary tectonics in the northern Tabas Block, east-central Iran: The Callovian (Middle Jurassic) Sikhor Formation. Facies, 48, 151-170.

Gale, A.S., Mutterlose, J., \& Batenburg, S. with contributions by Gradstein, F.M., Agterberg, F.P., Ogg, J.G., \& Petrizzo, M.R. (2020).The Cretaceous Period. In F.M. Gradstein, J.G. Ogg, M.D. Schmitz \& G.M. Ogg, (Eds.), Geologic Time Scale 2020, Volume 2 (pp. 1023-1086). Amsterdam: Elsevier.

Gèze, R., Veltz, I., Paicheler, J.-C., Granier, B., Habchi, R., Azar, D., $\&$ Maksoud, S. (2016). Preliminary report on a dinosaur tracksite from Lower Cretaceous strata in Mount Lebanon. Arabian Journal of Geosciences, 9, 730.

Goldring, R. (1999). Field palaeontology. $2^{\text {nd }}$ ed., 191pp.; Singapore: Longman.

Kazemi, Z., Ghasemi, H., Tilhac, R., Griffin, W., Shafaii Moghadam, H., O'Reilly, S., \& Mousivand, F. (2019). Late Cretaceous subduction-related magmatism on the southern edge of Sabzevar basin, NE Iran. Journal of the Geological Society, 176, 530-552.

Kellner, A. W. A., Dalla Vecchia, F. M., Mirzaie Ataabadi, M., De Paulo Silva, H., \& Khosravi, E. (2012). Review of the dinosaur record from Iran with the description of new material. Rivista Italiana Di Paleontologia e Stratigrafia, 118, 261-275.

Klein, H., Gierliński, G., Lallensack, J. N., Abu Hamad, A., \& 1-Mashakbeh, H., Alhejoj, I., Konopka, M., \& Błoński, M. . (2020). First Upper Cretaceous dinosaur track assemblage from Jordan (Middle East) - Preliminary results. Annales Societatis Geologorum Poloniae, 90, 331-342.

Lapparent, A. F., \& Davoudzadeh, M. (1972). Jurassic dinosaur footprints of the Kerman area, central Iran. Geological Survey of Iran, Report, 26, 5-22.

Lapparent, A. F., \& Nowgol Sadat, M. A. A. (1975). Une trace de pas de dinosaure dans le Lias de l'Elbourz, Iran. Comptes Rendus De L'académie Des Sciences Paris, Série D, 280, 161-163.

Leonardi, G. (1987). Glossary and manual of tetrapod footprint palaeoichnology (pp. 75, 20 pls). Brasília: Departamento Nacional da Produçao Mineral.

Lockley, M. (1991). Tracking dinosaurs: A new look at an ancient world (xii + pp. 238) New York: Cambridge University Press.

Lockley, M., \& Conrad, K. (1989). The paleoenvironmental context, preservation and paleoecological significance of dinosaur tracksites in the Western USA. In D.D. Gillette \& M.G. Lockley (Eds.), Dinosaur Tracks and Traces (pp. 121-134). Cambridge: University Press.
Marchetti, L., Belvedere, M., Voigt, S., Klein, H., Castanera, D., DíazMartínez, I., Marty, D., Xing, L., Feola, S., Melchor, R. N., \& Farlow, J. O. (2019). Defining the morphological quality of fossil footprints. Problems and principles of preservation in tetrapod ichnology with examples from the Palaeozoic to the present. EarthScience Reviews, 193, 109-145.

Marty, D. (2008). Sedimentology, taphonomy, and ichnology of Late Jurassic dinosaur tracks from the Jura carbonate platform (Chevenez-Combe Ronde tracksite, NW Switzerland): Insights into the tidal-flat palaeoenvironment and dinosaur diversity, locomotion, and palaeoecology. GeoFocus, 21, 1-278.

Marty, D., Cavin, L., Hug, W. A., Meyer, C. A., Lockley, M. G., \& Iberg, A. (2003). Preliminary report on the Courtedoux dinosaur tracksite from the Kimmeridgian of Switzerland. Ichnos, 10, 209-219.

Marty, D., Belvedere, M., Razzolini, N. L., Lockley, M. G., Paratte, G., Cattin, M., Lovis, C., \& Meyer, C. A. (2018). The tracks of giant theropods (Jurabrontes curtedulensis ichnogen. \& ichnosp. nov.) from the Late Jurassic of NW Switzerland: Palaeoecological \& palaeogeographical implications. Historical Biology, 30, 928-956.

Mattei, M., Cifelli, F., Muttoni, G., \& Rashid, H. (2015). Post-Cimmerian (Jurassic-Cenozoic) palaeogeography and vertical axis tectonic rotations of Central Iran and the Alborz Mountains. Journal of Asian Earth Sciences, 102, 92-101.

Meyer, C.A., Marty, D., Thüring, B., Thüring, S., \& Belvedere, M. (2021). The Late Cretaceous dinosaur track record of Bolivia Review and perspective. Journal of South American Earth Sciences, 106, 102992 (20 pp.).

Nasrabady, M., Rossetti, F., Theye, T., \& Vignaroli, G. (2011). Metamorphic history and geodynamic significance of the Early Cretaceous Sabzevar granulites (Sabzevar structural zone, NE Iran). Solid Earth, 2, 219-243.

Omrani, H., Moazzen, M., Oberhänsli, R., Altenberger, U., \& Lange, M. (2013). The Sabzevar blueschists of the North-Central Iranian micro-continent as remnants of the Neotethys-related oceanic crust subduction. International Journal of Earth Science, 102, 1491-1512.

Pirnia, T., Saccani, E., Torabi, G., Chiari, M., Goričan, S., \& Barbero, E. (2020). Cretaceous tectonic evolution of the Neo-Tethys in Central Iran: Evidence from petrology and age of the Nain-Ashin ophiolitic basalts. Geoscience Frontiers, 11, 57-81.

Razzolini, N. L., Oms, O., Castanera, D., Vila, B., dos Santos, V. F., \& Galobart, À. (2016). Ichnological evidence of megalosaurid dinosaurs crossing Middle Jurassic tidal flats. Scientific Reports, $6,31494$.

Saidi, A., Brunet, M.-F., \& Ricou, L.-E. (1997). Continental accretion of the Iran Block to Eurasia as seen from Late Paleozoic to Early Cretaceous subsidence curves. Geodinamica Acta, 10, 189-208.

Salehi, M. A., Moussavi-Harami, S. R., Mahboubi, A., Fürsich, F. T., Wilmsen, M., \& Heubeck, C. (2018). A tectono-stratigraphic record of an extensional basin: The Lower Jurassic Ab-Haji Formation of east-central Iran. Swiss Journal of Geosciences, 111, $51-78$.

Sarjeant, W.A.S., \& Leonardi, G. (1987). Substrate and footprints. In G. Leonardi (Ed.), Glossary and manual of tetrapod footprint palaeoichnology (p. 52). Brasília: Departamento Nacional da Produçao Mineral.

Schulp, A.S., Al-Wosabi, M., \& Stevens, N.J. (2008). First dinosaur tracks from the Arabian Peninsula. PLoS ONE, 3, e2243 (4 pp.).

Sengör, A.M.C., Altiner, D., Cin, A., Ustaömer, T., \& Hsü, K.J. (1988). Origin and assembly of the Tethysides orogenic collage at the expense of Gondwana Land. In M.G. Audley-Charles \& A. Hallam (Eds.), Gondwana and Tethys. Geological Society, London, Special Publication, 37, 119-181. 
Seyed-Emami, K., Fürsich, F. T., \& Wilmsen, M. (2004). Documentation and significance of tectonic events in the northern Tabas Block (east-central Iran) during the Middle and Late Jurassic. Rivista Italaliana Di Paleontologia e Stratigrafia, 110, 163-171.

Shamanian, G., \& Hattori, K. (2021). Neoproterozoic evolution of northern Gondwana recorded in detrital zircon grains from the Gheshlagh bauxite deposit, Alborz Mountains, Iran Block. Gondwana Research, 93, 184-196.

Soffel, H., Davoudzadeh, M., Rolf, C., \& Schmidt, S. (1996). New palaeomagnetic data from Central Iran and a Triassic palaeoreconstruction. Geologische Rundschau, 85, 293-302.

Stampfli, G. M., \& Borel, G. D. (2002). A plate tectonic model for the Paleozoic and Mesozoic constrained by dynamic plate boundaries and restored synthetic oceanic isochrones. Earth and Planetary Science Letters, 196, 17-33.

Stow, D.A.V. (2005). Sedimentary rocks in the field (pp. 1-320). London: Manson Publishing.

Taheri, J., Fürsich, F.T., \& Wilmsen, M. (2009). Stratigraphy, depositional environments, and geodynamic significance of the Upper Bajocian-Bathonian Kashafrud Formation (NE Iran). In M.-F. Brunet, M. Wilmsen \& J. Granath (Eds.), South Caspian to central Iran basins. Geological Society, London, Special Publication, 312, 205-218.

Takin, M. (1972). Iranian geology and continental drift in the Middle East. Nature, 235, 147-150.

Thulborn, T. (1990). Dinosaur tracks (xvii + pp. 410). London, New York, Tokyo, Melbourne, Madras: Chapman \& Hall.

Tirrul, R., Bell, I. R., Griffis, R. J., \& Camp, V. E. (1983). The Sistan suture zone of eastern Iran. Geological Society of America Bulletin, 94, 134-150.

Tucker, M.E. (2011). Sedimentary rocks in the field - A practical guide. $4^{\text {th }}$ edition, The Geological Field Guide Series (pp. 1-288). New York: John Wiley \& Sons.

Vila, B., Oms, O., Fondevilla, V., Gaete, R., Galobart, A., \& Canudo, J.I. (2013). The latest succession of dinosaur tracksites in Europe: Hadrosaur ichnology, track production and palaeoenvironments. PLoS ONE, 8, e72579 (15 pp.).

Vremir, M., \& Codrea, V. A. (2002). The first Late Cretaceous (Maastrichtian) dinosaur footprints from Transylvania (Romania). Studia Universitatis Babes-Boyai, Geologia, 47, 93-104.

Wilmsen, M., Fürsich, F. T., Seyed-Emami, K., Majidifard, M. R., \& Taheri, J. (2009). The Cimmerian orogeny in northern Iran:
Tectono-stratigraphic evidence from the foreland. Terra Nova, 21, 211-218.

Wilmsen, M., Fürsich, F. T., \& Majidifard, M. R. (2012). Porosphaera globularis (Phillips, 1829) (Porifera, Calcarea) from the Maastrichtian Farokhi Formation of Central Iran. Cretaceous Research, 33, 91-96.

Wilmsen, M., Fürsich, F. T., \& Majidifard, J. (2013). The Shah Kuh Formation, a latest Barremian - Early Aptian carbonate platform of Central Iran (Khur area, Yazd Block). Cretaceous Research, 39, 183-194.

Wilmsen, M., Fürsich, F. T., \& Majidifard, J. (2015). An overview of the Cretaceous stratigraphy and facies development of the Yazd Block, western Central Iran. Journal of Asian Earth Sciences, 102, 73-91.

Wilmsen, M., Berensmeier, M., Fürsich, F.T., Majidifard, M.R., \& Schlagintweit, F. (2018a). A Late Cretaceous epeiric carbonate platform: The Haftoman Formation of Central Iran. Facies, 64, 11 (24pp.).

Wilmsen, M., Storm, M., Fürsich, F.T., Majidifard, M.R., Schlagintweit, F., \& Hart, M. (2018b). The mid-Cretaceous Debarsu Formation (Upper Albian-Middle Turonian) of Central Iran: Depositional environment, palaeogeography, and sequence stratigraphic significance. Facies, 64, 29 (28pp.).

Wilmsen, M., Berensmeier, M., Fürsich, F.T., Schlagintweit, F., Hairapetian, V., Pashazadeh, B., \& Majidifard, M.R. (2020). Mid-Cretaceous biostratigraphy (ammonites, inoceramid bivalves and foraminifers) at the eastern margin of the Anarak Metamorphic Complex (Central Iran). Cretaceous Research, 110, article 104411 (21pp.).

Wilmsen, M., Fürsich, F. T., Seyed-Emami, K., \& Majidifard, M. R. (2021). The Upper Jurassic Garedu Red Bed Formation of the northern Tabas Block: Elucidating Late Cimmerian tectonics in east-Central Iran. International Journal of Earth Sciences, 110, 767-790.

Publisher's note Springer Nature remains neutral with regard to jurisdictional claims in published maps and institutional affiliations. 